\title{
A Study About the Relationships Between Perceived Leadership and Job Satisfaction in Fuel Sector
}

\author{
Professor Dr. Evren AYRANCI (Corresponding author) \\ Istanbul AREL University \\ Istanbul, Turkey \\ E-mail: evrenayranci@gmail.com
}

Serhat DEMIR

Shell Gasoline and Fuel Oil Station

Istanbul, Turkey

E-mail: serhat.dmr90@gmail.com

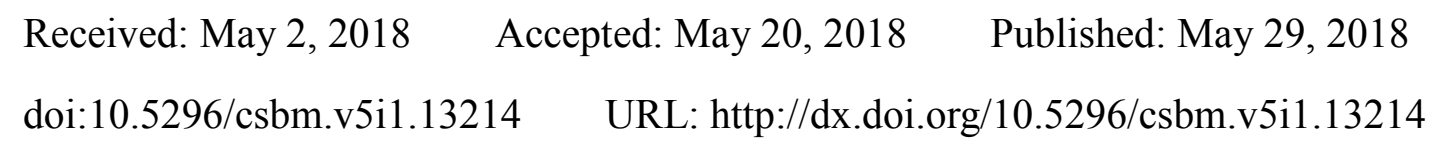

\begin{abstract}
Due to their popularity, there are countless studies about job satisfaction and leadership. With this aspect in mind, this study scrutinizes relationships between perceived leadership and job satisfaction in a rather less considered context: fuel sector. The participants of the study are workers of fuel stations, gathered from specific regions of Istanbul. According to results obtained, their job satisfaction depends on four factors; namely task, and social, managerial and institutional aspects. Another result reveals that they perceive their immediate managers as leaders and this perceived leadership is also made of four factors: inspirational, productive and laissez-faire styles, and success orientation. Although perceived leadership is unable to affect job satisfaction completely, there are some partial effects. A look on these partial effects reveals that most items of inspirational and laissez-faire leadership styles are effective on worker's job satisfaction. While success orientation feature of leadership can affect job satisfaction via one of its items solely, productive leadership style completely fails to affect the mentioned job satisfaction.
\end{abstract}

Keywords: Leadership, Job Satisfaction, Fuel Sector, Istanbul, Turkey 


\section{Introduction}

Leadership has been in the focus of humanity throughout history. Since the ancient times, many scholars have considered what leadership is, how it emerges, and how someone becomes a leader. This curiosity transformed into a scientific research area in the 19. Century and this area is addressed by many studies. When the business context is taken into account, the situation is similar: leadership in business context is a very popular subject. A consensus is that leadership is beneficial for businesses at individual, group, and organizational levels; moreover, it is a vital aspect of performance, competitiveness, growth, and survival.

Leadership, by its nature, is about people and their interactions. This is an important matter for businesses because the key element of any business is its people. In this sense, it is appropriate to think that good leadership practices could be positively effective on various worker-related issues such as organizational citizenship behavior, organizational justice perceptions, turnover, absenteeism, presenteeism, organizational alienation, productivity, stress, burnout, and job satisfaction.

These mentioned connections imply a vast variety of choices to study and authors of this study select job satisfaction in order to investigate. Job satisfaction is by far one of the most analyzed subjects in the domain of business and it is a very good indicator of worker-related outputs. In other words, job satisfaction is an influential matter on workers' ideas, attitudes, behaviors, performance, and sociality.

Therefore, authors of this study understand the importance of leadership and job satisfaction in the business context, and scrutinize possible effects of leadership on job satisfaction. As job satisfaction is mainly related to workers of a business, workers' job satisfaction is in question.

Leadership is also considered from workers' side; the nature of leadership makes it a relative and embraced concept: when people accept and obey an individual willingly for the common good, this individual becomes the leader. Authors, in this sense, emphasize workers' ideas about their immediate managers to reveal whether these managers are perceived as leaders.

Main goal of the study is to understand whether and how this perceived leadership affects workers' job satisfaction. Results indicate multi-factor leadership perception and job satisfaction structures, and partial effects of leadership factors on job satisfaction.

\section{Definition, Premises and Consequences of Job Satisfaction}

Individual in the work context has been an interesting subject for scholars since 1930s and thus many studies about individuals' job-related subjects have been made (Erdil et al., 2004). Contemporary management approaches posit that individuals' expectations regarding their tasks and work contexts should be met remarkably in order for businesses to reach desirable results and there should be an excellent compliance between business and its members for this reason (Butler, 1993) regardless of the technology used (Fu et al., 2011). Due to the fact that time in work context accounts of almost one thirds of individuals' daily time (Guney \& Arikan, 1994); business and business tasks are not solely important in economic terms, but 
they are also massively effective on individuals' emotional, physical and psychological well-being (Harter et al., 2003).

These facts bring up an important outcome: Job satisfaction is a vital aspect of business life. Satisfaction, which is generally defined as a feeling that results from contentment or a spiritual fulfillment (Kallampally et al., 2008), is considered as the felicity and serenity an individual gets from business tasks and business-related matters involving various aspects such as salary, social interactions, management and so on (Weiss, 2002) if job satisfaction is in question. While this definition focuses on the positive side of job satisfaction and is supported by some scholars (e.g. Singh et al., 2004); many other scholars (e.g. Vroom, 1964; Berry, 1997; Davis \& Newstrom, 1985) consider job satisfaction as a bi-fold concept and call it as an overall positive or negative feelings towards business context and business tasks.

Job satisfaction is a very popular subject (Judge, 2000) and it involves many individual and business related issues. A brief investigation of these issues, however, point out that premises and consequences of job satisfaction are by far the most prominent subjects considered within the domain of job satisfaction.

There are many premises of job satisfaction in the literature and these are investigated at individual and organizational levels. While individual premises of job satisfaction involve age (Kutlay, 2011), gender (Mason, 1994), education level (Tetik et al., 2008), marital status (Sanli, 2006), personality (Eren, 2000), hereditary characteristics (Arvey et al., 1991), habits (Staw et al., 1986), and intelligence (Keskin et al., 2004); organizational premises include payment (Cohen, 1972), physical working conditions (Fairbrother \& Warn, 2003), intensity of task controls (Caliskan, 2005), social atmosphere (Faragher et al., 2005), and organizational culture (Iscan \& Timuroglu, 2007).

A common fact in these mentioned and other similar studies is the emphasis on expectations regardless of the premise at hand. In other words, it is asserted that individuals form and have some expectations regarding business context and business tasks; thus they compare these expectations with their business-related experiences. The result can be job satisfaction or dissatisfaction if a bi-fold approach is taken into consideration. As this comparison is accepted as the basic mechanism underlying job satisfaction (Blackburn and Lawrence, 1995; McDonald and Makin, 2000), many individual and organizational premises are considered to be effective via this mechanism. For instance, individuals who are older are found out to be more satisfied with their jobs due to the fact that their business expectations evolve and become more realistic towards business issues (Davis \& Newstrom, 1985). Higher education level can boost the mentioned expectations and thus can jeopardize expectation-reality tradeoff (Gardner \& Oswald, 2002), while it also has the potential to form more realistic expectations thus a positive effect on job satisfaction (Organ, 1988). Gender is also effective on job satisfaction through this comparison mechanism. Men and women tend to form different expectations from their businesses and thus diversities in task characteristics or business systems can partially or entirely fulfill these expectations (Chusmir \& Parker, 2001).

It is important that this comparison mechanism has two sides and one side is related to individuals' own characteristics. The other side belongs to business itself, and is about how 
the business is run and tasks are structured. While a supportive management is perceived as a sign of allowing individuals to be free in order to fulfill their business related expectations (Pelfrene et al., 2003), coherence among peers can provide a positive social atmosphere and thus an affirmative approach to make the comparison (Meyer et al., 1989). This positiveness is also witnessed when payments and social benefits are satisfactory (Denes, 2003). Task structure is related to this comparison by means of many issues. One such is the task content. If the task is perceived to be interesting and meaningful, this comparison mechanism works for the benefit of a better job satisfaction (Wright \& Davis, 2003). Clarity about formal roles required for tasks at hand can hinder role conflicts, and therefore helps the individual to make a more objective expectation-reality comparison (Sin et al., 2002). Empowerment and higher self-authority towards the tasks are also beneficial for a constructive comparison (Seo et al., 2004).

Consequences of job satisfaction resemble its premises in terms of variability albeit they are broadly grouped as physical and psycho-social aspects. Generally speaking, negative psycho-social aspects involve stress (Kyriacou, 2001), burnout (Leung \& Lee, 2006; Spector, 1997), social isolation (Kovner et al., 2006), absenteeism (Schaumberg \& Flynn, 2017), and turnover (Poghosyan et al., 2017); while positive psycho-social aspects relate to work engagement (Simpson, 2009), organizational commitment (Zhao et al., 2007), motivation (Waddimba et al., 2017), organizational citizenship behavior (Lavy \& Littman-Ovadia, 2017), and life satisfaction (Judge \& Watanabe, 1993).

Physical aspects, on the other hand, are considered rather from a negative perspective and involve heart diseases (Heponiemi et al., 2014), illnesses (Kalliath \& Morris, 2002), and some psychosomatic complaints (Piko, 2006). A noteworthy point is that many studies (e.g. Faragher et al., 2005) consider these aspects simultaneously and some (e.g. Nadinloyi et al., 2013) moreover posit that these aspects interact.

\section{Leadership and Job Satisfaction Relationship in Business Context}

Despite being a noteworthy subject since ancient times, leadership has become a scientific subject of curiosity since the $19^{\text {th }}$ Century (e.g. James, 1880) and many leadership paradigms were born in the $20^{\text {th }}$ Century. Today, leadership literature itself is a jungle by means of various and even sometimes contradicting approaches. This jungle, however, is generally considered from four different angles.

As expected, the first approach is the traits theory (Gehring, 2007), which posits that leadership could only be traced via individual's authentic personality, physical properties or character (Cater, 2006). Due to many critiques (e.g. Stogdill, 1948); a new paradigm, which considers leadership behaviours, flourishes afterwards (Hemphill \& Coons, 1950) and emphasizes how a leader should behave (Mouton \& Blake, 1984). This correct set of behaviours becomes a point of conflict among scholars later, thus a need for a reconsideration of leadership is appealed (Korman, 1966). This reconsideration leads to the third main paradigm, which depends on contingencies when leadership is in question. In other words, scholars (e.g. Fiedler, 1967; Vroom \& Yetton, 1973) assert that there is no single set of correct leadership behaviours, thus leadership behaviours should be shaped in accordance 
with the contingencies. Finally, scholars argue that leadership cannot be limited to behaviours solely, and this argument leads to the fourth point of view: the modern leadership paradigm. This last paradigm involves various different leadership approaches, some of which can be briefed as charismatic (Howell \& Shamir, 2005), transactional (Bryant, 2003), transformational (Simons, 1999), strategic (Ireland \& Hitt, 1999), spiritual (Ayranci \& Semercioz, 2011), servant (Van Dierendonck, 2011), and authentic (Walumbwa et al., 2008) leadership.

Interestingly, this variety in approaches applies to definitions of leadership. Some early definitions emphasize the role of leadership as an instrument to achieve certain goals. For example, Cowley (1928) defines leadership as an effort to move towards a certain goal with a specific group in a specific manner. Bellows (1959) considers leadership as the arrangement of situations in order for the leader and followers to achieve the main goals in the most efficient way possible. This emphasis later enlarges and involves followers' goals and needs (Calder, 1977). Some scholars posit that this instrumentality should not be the primary role of leadership; effects and interactions should be under the spotlights. Bogardus (1929), in this case, posits that leadership is a social interpersonal stimulation in order for followers to turn their attentions to common goals and become more encouraged towards goal achievement. Redl (1942) considers leadership to be the capacity of stimulating others towards common goals via interplays of personal differences. Regardless of goals or interactions, another definition priorities leadership process. A noteworthy point about this approach is that the mentioned process is considered to be an interactive two-way process (Dansereau et al., 1975). In other words, there are exchanges between the leader and followers (Northouse, 2001) and these exchanges enable the leader to understand what followers need and how they perceive common goals; thus helps the leader to reconsider own leadership (Portugal and Yuk1, 1994). This approach is also altered by some scholars (e.g. Janda, 1960) and a sole one-way effect that depends on the perceived power of leader is claimed to exist. On the contrary, some scholars (e.g. Gibb, 1954) consider this power emphasis to be futile and claim that leadership is just a differentiated role. Group members need to play various roles to achieve common goals and leadership is solely one of these roles (Jennings, 1944). A further approach calls for followers' perceptions and leadership is posited to be one of the roles in a group that emerges once others perceive a specific member as a leader (Colbert, 2003). A related understanding moreover states that this perception should be ushered with emotional ties (Shamir, 1991). Finally, the abundance of these paradigms urges scholars to take multiple approaches into account when defining leadership and thus combinations of the mentioned approaches are used to point out the nature of leadership (e.g. House et al., 2004; Tichy and Devanna, 1986).

Research related to leadership in business context reaches to the consensus that leadership is usually beneficial at individual (Liden et al., 2008), group (Voegtlin et al., 2012), and organizational (Mumford et al., 2007) levels. Moreover, these benefits can be observed when different styles such as transformational (Epitropaki \& Martin, 2013), transactional (Bryant, 2003), innovation (Lindgren, 2012), and spiritual (Dede \& Ayranci, 2014) leadership are applied within business context. 


\section{Macrothink}

Case Studies in Business and Management

ISSN 2333-3324

2018, Vol. 5, No. 1

These mentioned benefits are witnessed not only at various levels, but also in terms of many organizational subjects. Scholars, for instance, unearth that leadership fosters a positive atmosphere over the organization and thus increases business unit performance (Xenikou \& Simosi, 2006); leadership applications can be beneficial to overcome glass ceiling problems (Eagly \& Carli, 2007); proper leadership can motivate business members to act more ethically (Minkes et al., 1999); innovation performance is positively affected by successful leadership (Howell \& Avolio, 1993); family businesses enjoy leadership when it is combined with intra-family ties (Ward, 2011); leadership affects entrepreneurship success (Chung-Wen, 2008); good leadership practices cause better customer satisfaction (Galbreath \& Rogers, 1999); and leadership lessens the intensity of business members' burnout (Kanste et al., 2007), turnover intentions (Ali et al., 2014), work alienation (Sarros et al., 2002), presenteeism (Nielsen \& Daniels, 2016), and absenteeism (Frooman et al., 2012).

As expected, leadership's benefits continue when job satisfaction is in question and these benefits are multifaceted. Leadership is useful in terms of providing workers' satisfaction with the leader (Judge \& Piccolo, 2004), which in turn, boosts their motivation towards their tasks (Bono \& Judge, 2003). This motivation boost shows itself in the form of greater task commitment (DeGroot et al., 2000) and ultimately better job satisfaction (Braun et al., 2013). These findings prove that leadership-job satisfaction relationship has an underlying mechanism and a brief literature review points out that this mechanism is not limited to the mentioned subjects, thus many other factors should be taken into account. For instance, leadership can enable workers to exhibit their innovativeness towards their tasks and this permissiveness can be an agent of job satisfaction (Sarros et al., 2008). Leader's empowerment of workers can also act as a similar agent because workers could have the feeling of being trusted and the possibility of exerting their own ideas (Bryant, 2003). If workers are to perform same tasks repeatedly, leader's support can be used to diminish the negative effects of dullness, thus the possibility of reductions in job satisfaction (Wong \& Cummings, 2007). This support may need to include emotionality if workers' deep commitment is required (Kellett et al., 2002). Regardless of the subjects included in the mechanism, a noteworthy finding is that leadership can build up workers' trust towards work context and this trust can foster job satisfaction at least in terms of emotional bonds with the business (Pillai et al., 1999).

\section{Methodology}

In this part, possible relationships between workers' job satisfaction and their perceptions about their immediate managers' leadership styles are scrutinized within the domain of fuel sector in Istanbul, Turkey.

\subsection{Aim, Importance, Population and Sample of the Research}

As already mentioned, organizational success heavily depends on its workers and thus workers' job satisfaction is a crucial aspect. Leadership is also found out to be advantageous for many business related issues, including job satisfaction itself. These are the underlying facts for the aim of the current research. 


\section{Macrothink}

Therefore, the research initially aims to find out how workers' job satisfaction and their perceptions about their immediate managers' leadership styles are statistically structured. Afterwards, the main aim is to find out whether and how these structured job satisfaction and leadership perceptions are related.

Despite the abundance of similar studies, the research is considered to be important for some specific reasons. First, it gives an insight about the mentioned subject when the Turkish context is in question. Second, it considers a rather scarce field: fuel sector, which requires great efforts of workers to get tasks done.

With these in mind, the population is initially considered as all workers in fuel stations in the European side of Istanbul city. The reason for the choice of this region is that it is heavily used for commercial activities and it also acts as a central motorway to connect Turkey with the Europe. As there are numerous fuel stations in this region, the sample is determined to be composed of workers in fuel stations in specific districts, which are the biggest ones in terms of commercial activities. Thus, the fuel stations in the districts of Bahcesehir, Bayrampasa, Catalca, Esenler, Esenyurt, Gaziosmanpasa and Mahmutbey are taken into account.

\subsection{Model and Data Collection Method}

In congruence with the main research aim, the following hypothesis is suggested along with a research model:

Ho: Workers' perceptions about their immediate managers' leadership affect their own job satisfaction.

Therefore, the related research model that denotes this hypothesis is given in Figure 1.

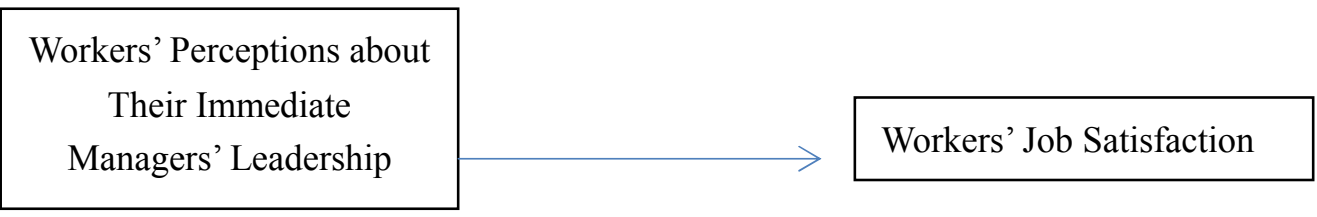

Figure 1. Proposed research model

Data are collected via questionnaires and there are three parts included. In the first part, data regarding participants' demographic features and their sectorial expertise are in question. The second part is composed of items that originally belong to Minnesota Job Satisfaction Scale (Weiss et al., 1967) and thus consider participants' job satisfaction. The last part involves perceived leadership and depends on multifactor leadership model that belongs to Bass (1985).

After data collection, as a pilot study, exploratory factor and reliability analyses are run in order to find out statistical structures of job satisfaction and perceived leadership. For this purpose, data from 45 participants are used. In the next step, these structures are taken into 


\section{Macrothink}

Case Studies in Business and Management

ISSN 2333-3324

2018, Vol. 5, No. 1

consideration while scrutinizing relationships between these two concepts with data from 85 participants.

\subsection{Statistical Structures Emerged}

The first exploratory factor analysis is run for job satisfaction items as seen in Table 1. While the data is suitable for factorization (KMO: 0.830 and Bartlett test value is statistically significant), there are four factors emerged that can explain $66.31 \%$ of the overall variance.

Table 1. Exploratory factor analysis results for job satisfaction

\begin{tabular}{|c|c|c|c|c|}
\hline Job Satisfaction Due to ... & $\begin{array}{l}\text { Social } \\
\text { Aspect }\end{array}$ & Task & $\begin{array}{l}\text { Managerial } \\
\text { Aspect }\end{array}$ & $\begin{array}{l}\text { Institutional } \\
\text { Aspect }\end{array}$ \\
\hline Doing something for others (9) & 0.786 & & & \\
\hline Working with my co-workers (10) & 0.776 & & & \\
\hline Friendship with my co-workers (18) & 0.733 & & & \\
\hline $\begin{array}{l}\text { The possibility of having a social environment } \\
\text { (8) }\end{array}$ & 0.644 & & & \\
\hline Using my social skills (11) & 0.601 & & & \\
\hline My manager's behavior towards us (5) & 0.503 & & & \\
\hline Freedom (13) & & 0.805 & & \\
\hline $\begin{array}{l}\text { The possibility of making my own task } \\
\text { decisions (15) }\end{array}$ & & 0.707 & & \\
\hline The possibility of a promotion (14) & & 0.691 & & \\
\hline My working conditions (17) & & 0.632 & & \\
\hline The possibility to work alone (2) & & 0.528 & & \\
\hline $\begin{array}{l}\text { My confidence and safety related to what I do } \\
\text { (16) }\end{array}$ & & 0.522 & & \\
\hline Rewards I get (20) & & & 0.800 & \\
\hline Being appreciated by my business (19) & & & 0.766 & \\
\hline $\begin{array}{l}\text { My manager's competence in decision making } \\
\text { (6) }\end{array}$ & & & 0.730 & \\
\hline My manager's professional behavior (7) & & & 0.630 & \\
\hline The possibility of in-business job rotations (3) & & & & 0.767 \\
\hline $\begin{array}{l}\text { The possibility of continuous task related } \\
\text { improvements (1) }\end{array}$ & & & & 0.633 \\
\hline Fair business policies applied (12) & & & & 0.550 \\
\hline $\begin{array}{l}\text { The possibility of getting a continuous position } \\
\text { in the business ( } 4 \text { ) }\end{array}$ & & & & 0.545 \\
\hline
\end{tabular}

Extraction Method: Principal Component Analysis.

Rotation Method: Varimax with Kaiser Normalization.

Rotation converged in 7 iterations. 
As seen in Table 1, the first factor is the social aspect of job satisfaction and it involves social interactions with the peers, manager, and the general social atmosphere. The second factor, task, denotes how the tasks are performed while the third one, managerial aspect, is related to appreciation of the worker and manager's professionalism. The fourth and last factor is the institutional aspect, which is about professionalization of the business in terms of policies, tasking, and staffing.

For the next step, reliability analyses are performed on each factor's items as well as on all the items in general. The results are given in Table 2.

Table 2. Reliability analyses results for job satisfaction

\begin{tabular}{ll}
\hline Factor & Cronbach's Alpha Values \\
\hline Social Aspect & 0.862 \\
Task & 0.844 \\
Managerial Aspect & 0.834 \\
Institutional Aspect & 0.815 \\
\hline All Items & 0.930 \\
\hline
\end{tabular}

Table 2 clearly points out that the items under each respective factor and all of the items have very high reliability levels.

As the statistical structure of job satisfaction items is figured out, leadership perceptions towards the immediate manager should be investigated in statistical terms. Table 3 involves the results of exploratory factor analysis results for this perception. Workers' leadership perceptions towards their immediate manager are composed of four factors aggregately (KMO: 0.9 and Bartlett's test value is statistically significant), and these factors can explain $72.476 \%$ of the total variance. 


\section{Macrothink}

Case Studies in Business and Management

ISSN 2333-3324

2018, Vol. 5, No. 1

Table 3. Exploratory factor analysis results for leadership perceptions

\begin{tabular}{|c|c|c|c|c|}
\hline My Immediate Manager... & $\begin{array}{l}\text { Inspirational } \\
\text { Style }\end{array}$ & $\begin{array}{l}\text { Productive } \\
\text { Style }\end{array}$ & $\begin{array}{l}\text { Laissez-faire } \\
\text { Style }\end{array}$ & $\begin{array}{l}\text { Success } \\
\text { Orientation }\end{array}$ \\
\hline Avoids making decisions by oneself (16) & 0.849 & & & \\
\hline Creates confidence that the targets will be met (18) & 0.825 & & & \\
\hline Makes optimistic speeches about the future (24) & 0.761 & & & \\
\hline $\begin{array}{l}\text { Treats workers individually, rather than as a member } \\
\text { of the group (27) }\end{array}$ & 0.753 & & & \\
\hline $\begin{array}{l}\text { Identifies responsibilities of workers to achieve the } \\
\text { intended objectives (26) }\end{array}$ & 0.751 & & & \\
\hline $\begin{array}{l}\text { Considers spiritual and ethical consequences of } \\
\text { decisions (21) }\end{array}$ & 0.743 & & & \\
\hline Emphasizes the common sense of duty (17) & 0.738 & & & \\
\hline Praises us for being in cooperation with him / her (25) & 0.738 & & & \\
\hline Spends time to educate and help workers (20) & 0.733 & & & \\
\hline $\begin{array}{l}\text { Re-examines the suitability of critical decisions by } \\
\text { questioning (23) }\end{array}$ & 0.716 & & & \\
\hline Strives to keep our enthusiasm alive (28) & 0.697 & & & \\
\hline Trusts us (19) & 0.688 & & & \\
\hline $\begin{array}{l}\text { Listens us to understand different approaches for } \\
\text { problems (22) }\end{array}$ & 0.677 & & & \\
\hline Is open to criticism (15) & 0.554 & & & \\
\hline $\begin{array}{l}\text { Gives up own interests for the benefits of the worker } \\
\text { group (6) }\end{array}$ & 0.506 & & & \\
\hline Produces new projects (14) & & 0.805 & & \\
\hline Exhibits a sense of power and confidence (11) & & 0.793 & & \\
\hline Encourages new ideas (10) & & 0.711 & & \\
\hline Delays answering urgent questions (13) & & 0.662 & & \\
\hline Emphasizes the corporate vision (12) & & 0.570 & & \\
\hline Does not exist when needed (2) & & & 0.881 & \\
\hline $\begin{array}{l}\text { Does not interfere when there are no serious } \\
\text { problems (1) }\end{array}$ & & & 0.859 & \\
\hline $\begin{array}{l}\text { Waits for things to get worse before actively } \\
\text { engaging in (3) }\end{array}$ & & & 0.786 & \\
\hline $\begin{array}{l}\text { Provides resources to workers in order to reach the } \\
\text { specified objectives (5) }\end{array}$ & & & 0.600 & \\
\hline Does not clearly manage us (4) & & & 0.568 & \\
\hline Makes motivational speeches to achieve success (8) & & & & 0.748 \\
\hline $\begin{array}{l}\text { Emphasizes mistakes, complaints and deficiencies } \\
\text { (9) }\end{array}$ & & & & 0.602 \\
\hline $\begin{array}{l}\text { Produces appropriate and constructive solutions for } \\
\text { problems (7) }\end{array}$ & & & & 0.595 \\
\hline Extraction Method: Principal Component Analysis. & & & & \\
\hline Rotation Method: Varimax with Kaiser Normalization. & & & & \\
\hline Rotation converged in 8 iterations. & & & & \\
\hline
\end{tabular}




\section{Macrothink}

Case Studies in Business and Management

ISSN 2333-3324

2018, Vol. 5, No. 1

It is understood from Table 3 that the inspirational style of the leader has many facets; it involves leader's democratic approach, responsibility, emphasis on workers, providing enthusiasm, trust forming, and acceptance of criticism. The second factor, productive style, focuses on leader's production, emphasis on new ideas, and acting slowly and deeply towards questions while considering corporate vision. Laissez-faire style simply refers the extent to which the leader does not get involved in business matters and rather prefers to lead in the shadows. Finally, success orientation is about leader's motivation for success and problem solving eagerness.

The reliabilities of the structure are checked and the relevant results are in Table 4. It unveils that there is no reliability problem regarding leadership perceptions.

Table 4. Reliability analyses results for leadership perceptions

\begin{tabular}{ll}
\hline Factor & Cronbach's Alpha Values \\
\hline Inspirational Style & 0.958 \\
Productive Style & 0.909 \\
Laissez-faire Style & 0.891 \\
Success Orientation & 0.827 \\
\hline All Items & 0.956 \\
\hline
\end{tabular}

\subsection{Relationships Between Workers' Job Satisfaction and Their Perceptions About Their Immediate Managers' Leadership}

The research model in Figure 1 is considered in this section with the intention to test the main hypothesis. The test is made using a general linear model (GLM), as it is an appropriate way to use when there are many dependent and independent variables (Mensah, 2017).

Table 5 shows the aggregate results about managers' perceived inspirational leadership style's effects on workers' job satisfaction. 


\section{Macrothink}

Case Studies in Business and Management

ISSN 2333-3324

2018, Vol. 5, No. 1

Table 5. GLM results about perceived inspirational leadership style's effects on job satisfaction

Multivariate Tests ${ }^{\mathrm{a}}$

\begin{tabular}{|c|c|c|c|c|c|c|c|c|c|}
\hline Effect & & Value & $\mathrm{F}$ & $\begin{array}{l}\text { Hypothes } \\
\text { is df }\end{array}$ & Error df & Sig. & $\begin{array}{l}\text { Partial Eta } \\
\text { Squared }\end{array}$ & $\begin{array}{l}\text { Noncent. } \\
\text { Parameter }\end{array}$ & $\begin{array}{l}\text { Observed } \\
\text { Power }^{\mathrm{d}}\end{array}$ \\
\hline \multirow{4}{*}{ Intercept } & Pillai's Trace & .895 & $2.996^{\mathrm{b}}$ & 20.000 & 7.000 & .071 & .895 & 59.927 & .656 \\
\hline & Wilks' Lambda & .105 & $2.996^{\mathrm{b}}$ & 20.000 & 7.000 & .071 & .895 & 59.927 & .656 \\
\hline & Hotelling's Trace & 8.561 & $2.996^{\mathrm{b}}$ & 20.000 & 7.000 & .071 & .895 & 59.927 & .656 \\
\hline & $\begin{array}{l}\text { Roy's Largest } \\
\text { Root }\end{array}$ & 8.561 & $2.996^{\mathrm{b}}$ & 20.000 & 7.000 & .071 & .895 & 59.927 & .656 \\
\hline \multirow{3}{*}{$\begin{array}{l}\text { Gives up own } \\
\text { interests for the } \\
\text { benefits of the } \\
\text { worker group ( } 6)\end{array}$} & Wilks' Lambda & .001 & 3.436 & 60.000 & 21.719 & .001 & .903 & 203.231 & .998 \\
\hline & Hotelling's Trace & 46.368 & 4.379 & 60.000 & 17.000 & .001 & .939 & 262.752 & .999 \\
\hline & $\begin{array}{l}\text { Roy's Largest } \\
\text { Root }\end{array}$ & 35.777 & $16.100^{\mathrm{c}}$ & 20.000 & 9.000 & .000 & .973 & 321.996 & 1.000 \\
\hline \multirow{3}{*}{$\begin{array}{l}\text { Is open to } \\
\text { criticism (15) }\end{array}$} & Pillai's Trace & 3.135 & 1.813 & 80.000 & 40.000 & .020 & .784 & 145.001 & .990 \\
\hline & Wilks' Lambda & .001 & 2.013 & 80.000 & 30.035 & .017 & .839 & 156.242 & .981 \\
\hline & $\begin{array}{l}\text { Roy's Largest } \\
\text { Root }\end{array}$ & 22.577 & $11.289^{c}$ & 20.000 & 10.000 & .000 & .958 & 225.773 & 1.000 \\
\hline \multirow{4}{*}{$\begin{array}{l}\text { Avoids making } \\
\text { decisions by } \\
\text { oneself (16) }\end{array}$} & Pillai's Trace & 2.449 & 2.000 & 60.000 & 27.000 & .025 & .816 & 119.992 & .967 \\
\hline & Wilks' Lambda & .004 & 1.911 & 60.000 & 21.719 & .048 & .839 & 113.276 & .917 \\
\hline & Hotelling's Trace & 18.739 & 1.770 & 60.000 & 17.000 & .046 & .862 & 106.185 & .819 \\
\hline & $\begin{array}{l}\text { Roy's Largest } \\
\text { Root }\end{array}$ & 11.955 & $5.380^{\mathrm{c}}$ & 20.000 & 9.000 & .007 & .923 & 107.598 & .965 \\
\hline
\end{tabular}




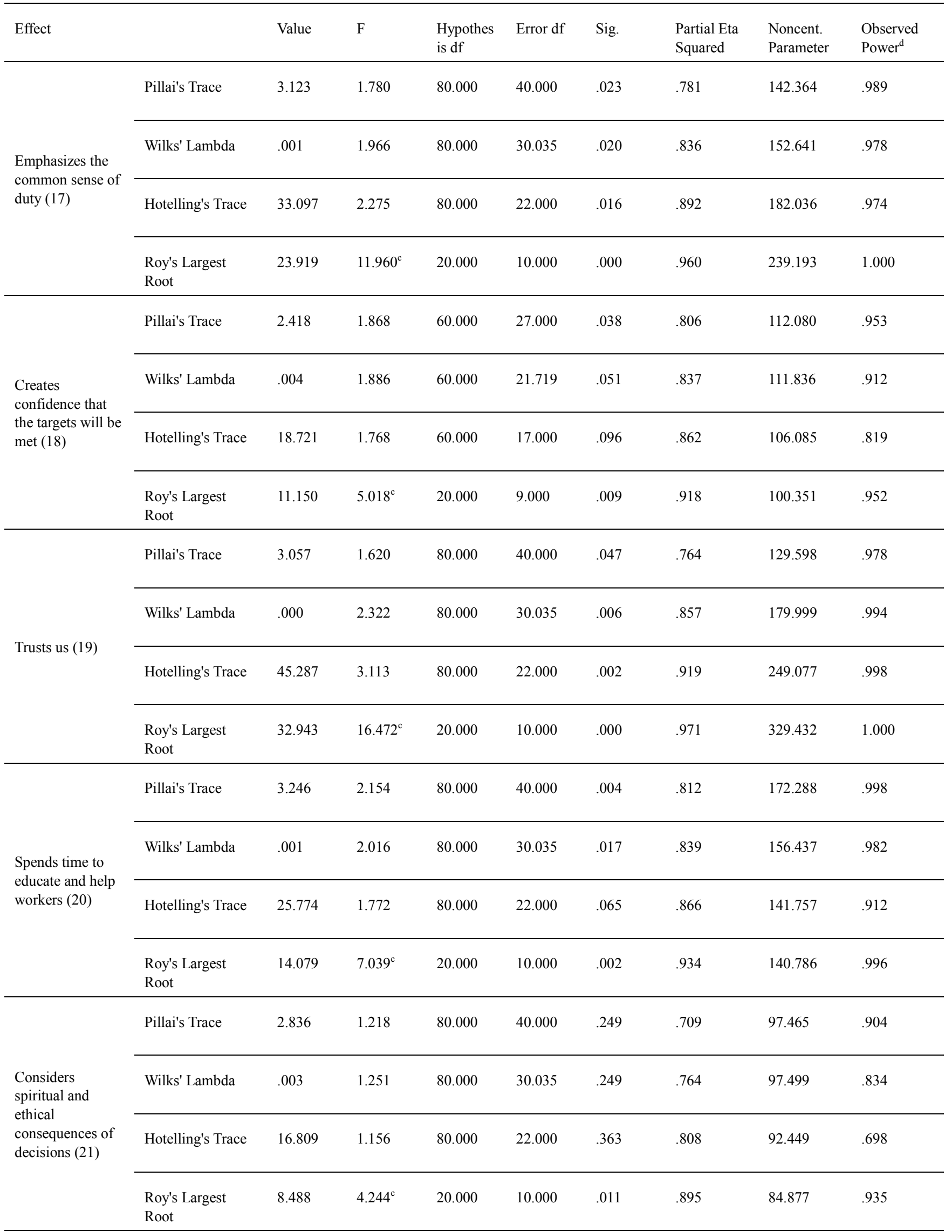




\begin{tabular}{|c|c|c|c|c|c|c|c|c|c|}
\hline Effect & & Value & $\mathrm{F}$ & $\begin{array}{l}\text { Hypothes } \\
\text { is df }\end{array}$ & Error df & Sig. & $\begin{array}{l}\text { Partial Eta } \\
\text { Squared }\end{array}$ & $\begin{array}{l}\text { Noncent. } \\
\text { Parameter }\end{array}$ & $\begin{array}{l}\text { Observed } \\
\text { Power }^{\mathrm{d}}\end{array}$ \\
\hline \multirow{4}{*}{$\begin{array}{l}\text { Listens us to } \\
\text { understand } \\
\text { different } \\
\text { approaches for } \\
\text { problems (22) }\end{array}$} & Pillai's Trace & 2.962 & 1.427 & 80.000 & 40.000 & .108 & .741 & 114.176 & .954 \\
\hline & Wilks' Lambda & .002 & 1.388 & 80.000 & 30.035 & .158 & .782 & 108.040 & .882 \\
\hline & Hotelling's Trace & 17.759 & 1.221 & 80.000 & 22.000 & .306 & .816 & 97.673 & .731 \\
\hline & $\begin{array}{l}\text { Roy's Largest } \\
\text { Root }\end{array}$ & 9.017 & $4.508^{\mathrm{c}}$ & 20.000 & 10.000 & .009 & .900 & 90.168 & .949 \\
\hline \multirow{3}{*}{$\begin{array}{l}\text { Re-examines the } \\
\text { suitability of } \\
\text { critical decisions } \\
\text { by questioning } \\
(23)\end{array}$} & Wilks' Lambda & .002 & 1.442 & 80.000 & 30.035 & .131 & .789 & 112.260 & .898 \\
\hline & Hotelling's Trace & 24.149 & 1.660 & 80.000 & 22.000 & .090 & .858 & 132.818 & .887 \\
\hline & $\begin{array}{l}\text { Roy's Largest } \\
\text { Root }\end{array}$ & 16.394 & $8.197^{\mathrm{c}}$ & 20.000 & 10.000 & .001 & .943 & 163.935 & .999 \\
\hline \multirow{3}{*}{$\begin{array}{l}\text { Makes optimistic } \\
\text { speeches about } \\
\text { the future }(24)\end{array}$} & Pillai's Trace & 2.675 & 3.709 & 60.000 & 27.000 & .000 & .892 & 222.562 & 1.000 \\
\hline & Wilks' Lambda & .001 & 3.669 & 60.000 & 21.719 & .001 & .909 & 216.975 & .999 \\
\hline & $\begin{array}{l}\text { Roy's Largest } \\
\text { Root }\end{array}$ & 24.795 & $11.158^{\mathrm{c}}$ & 20.000 & 9.000 & .000 & .961 & 223.152 & 1.000 \\
\hline \multirow{4}{*}{$\begin{array}{l}\text { Praises us for } \\
\text { being in } \\
\text { cooperation with } \\
\text { him/her }(25)\end{array}$} & Pillai's Trace & 3.283 & 2.290 & 80.000 & 40.000 & .002 & .821 & 183.184 & .999 \\
\hline & Wilks' Lambda & .000 & 2.863 & 80.000 & 30.035 & .001 & .881 & 221.446 & .999 \\
\hline & Hotelling's Trace & 57.624 & 3.962 & 80.000 & 22.000 & .000 & .935 & 316.934 & 1.000 \\
\hline & $\begin{array}{l}\text { Roy's Largest } \\
\text { Root }\end{array}$ & 44.955 & $22.478^{\mathrm{c}}$ & 20.000 & 10.000 & .000 & .978 & 449.553 & 1.000 \\
\hline \multirow{4}{*}{$\begin{array}{l}\text { Identifies } \\
\text { responsibilities of } \\
\text { workers to } \\
\text { achieve the } \\
\text { intended } \\
\text { objectives (26) }\end{array}$} & Pillai's Trace & 2.302 & 1.483 & 60.000 & 27.000 & .131 & .767 & 88.993 & .875 \\
\hline & Wilks' Lambda & .007 & 1.559 & 60.000 & 21.719 & .126 & .810 & 92.493 & .832 \\
\hline & Hotelling's Trace & 16.379 & 1.547 & 60.000 & 17.000 & .160 & .845 & 92.816 & .748 \\
\hline & $\begin{array}{l}\text { Roy's Largest } \\
\text { Root }\end{array}$ & 10.840 & $4.878^{\mathrm{c}}$ & 20.000 & 9.000 & .010 & .916 & 97.556 & .946 \\
\hline
\end{tabular}




\begin{tabular}{|c|c|c|c|c|c|c|c|c|c|}
\hline Effect & & Value & $\mathrm{F}$ & $\begin{array}{l}\text { Hypothes } \\
\text { is df }\end{array}$ & Error df & Sig. & $\begin{array}{l}\text { Partial Eta } \\
\text { Squared }\end{array}$ & $\begin{array}{l}\text { Noncent. } \\
\text { Parameter }\end{array}$ & $\begin{array}{l}\text { Observed } \\
\text { Power }^{\mathrm{d}}\end{array}$ \\
\hline \multirow{4}{*}{$\begin{array}{l}\text { Treats workers } \\
\text { individually. } \\
\text { rather than as a } \\
\text { member of the } \\
\text { group (27) }\end{array}$} & Pillai's Trace & 2.259 & 1.373 & 60.000 & 27.000 & .184 & .753 & 82.366 & .839 \\
\hline & Wilks' Lambda & .012 & 1.213 & 60.000 & 21.719 & .317 & .768 & 72.010 & .694 \\
\hline & Hotelling's Trace & 10.782 & 1.018 & 60.000 & 17.000 & .511 & .782 & 61.099 & .512 \\
\hline & $\begin{array}{l}\text { Roy's Largest } \\
\text { Root }\end{array}$ & 5.641 & $2.538^{\mathrm{c}}$ & 20.000 & 9.000 & .076 & .849 & 50.766 & .682 \\
\hline \multirow{4}{*}{$\begin{array}{l}\text { Strives to keep } \\
\text { our enthusiasm } \\
\text { alive (28) }\end{array}$} & Pillai's Trace & 2.384 & 1.740 & 60.000 & 27.000 & .048 & .795 & 104.402 & .934 \\
\hline & Wilks' Lambda & .003 & 2.117 & 60.000 & 21.719 & .028 & .852 & 125.471 & .947 \\
\hline & Hotelling's Trace & 26.233 & 2.478 & 60.000 & 17.000 & .020 & .897 & 148.654 & .946 \\
\hline & $\begin{array}{l}\text { Roy's Largest } \\
\text { Root }\end{array}$ & 19.684 & $8.858^{\mathrm{c}}$ & 20.000 & 9.000 & .001 & .952 & 177.159 & .999 \\
\hline
\end{tabular}

a. Design: Intercept $+6+15+16+17+18+19+20+21+22+23+24+25+26+27+28$

b. Exact statistic

c. The statistic is an upper bound on $\mathrm{F}$ that yields a lower bound on the significance level.

d. Computed using alpha $=.05$

Table 5 points out a partial effect of the mentioned perceived leadership style on job satisfaction. In other words; most items such as "Gives up own interests for the benefits of the worker group", "Is open to criticism", "Avoids making decisions by oneself", "Emphasizes the common sense of duty", "Trusts us", "Makes optimistic speeches about the future", "Praises us for being in cooperation with him/her", "Strives to keep our enthusiasm alive" are effective on workers' job satisfaction. This finding implies that altruism, unity, and optimism aspects of managers' perceived inspirational leadership factor is important for the job satisfaction.

The next factor-productive style - is considered in terms of its effects on workers' job satisfaction in Table 6. 


\section{Macrothink}

Case Studies in Business and Management

ISSN 2333-3324

2018, Vol. 5, No. 1

Table 6. GLM results about perceived productive leadership style's effects on job satisfaction

\section{Multivariate Tests $^{\mathrm{a}}$}

\begin{tabular}{|c|c|c|c|c|c|c|c|c|c|}
\hline Effect & & Value & $\mathrm{F}$ & $\begin{array}{l}\text { Hypothesis } \\
\text { df }\end{array}$ & Error df & Sig. & $\begin{array}{l}\text { Partial Eta } \\
\text { Squared }\end{array}$ & $\begin{array}{l}\text { Noncent. } \\
\text { Parameter }\end{array}$ & $\begin{array}{l}\text { Observed } \\
\text { Power }^{\mathrm{d}}\end{array}$ \\
\hline \multirow{4}{*}{ Intercept } & Pillai's Trace & .932 & $30.776^{\mathrm{b}}$ & 20.000 & 45.000 & .000 & .932 & 615.522 & 1.000 \\
\hline & Wilks' Lambda & .068 & $30.776^{\mathrm{b}}$ & 20.000 & 45.000 & .000 & .932 & 615.522 & 1.000 \\
\hline & $\begin{array}{l}\text { Hotelling's } \\
\text { Trace }\end{array}$ & 13.678 & $30.776^{\mathrm{b}}$ & 20.000 & 45.000 & .000 & .932 & 615.522 & 1.000 \\
\hline & $\begin{array}{l}\text { Roy's Largest } \\
\text { Root }\end{array}$ & 13.678 & $30.776^{\mathrm{b}}$ & 20.000 & 45.000 & .000 & .932 & 615.522 & 1.000 \\
\hline \multirow{4}{*}{$\begin{array}{l}\text { Encourages new } \\
\text { ideas (10) }\end{array}$} & Pillai's Trace & 1.316 & 1.177 & 80.000 & 192.000 & .185 & .329 & 94.127 & .997 \\
\hline & Wilks' Lambda & .187 & 1.191 & 80.000 & 179.941 & .170 & .342 & 93.702 & .996 \\
\hline & $\begin{array}{l}\text { Hotelling's } \\
\text { Trace }\end{array}$ & 2.214 & 1.204 & 80.000 & 174.000 & .158 & .356 & 96.327 & .997 \\
\hline & $\begin{array}{l}\text { Roy's Largest } \\
\text { Root }\end{array}$ & 1.055 & $2.532^{\mathrm{c}}$ & 20.000 & 48.000 & .004 & .513 & 50.650 & .985 \\
\hline \multirow{4}{*}{$\begin{array}{l}\text { Exhibits a sense } \\
\text { of power and } \\
\text { confidence } \\
\text { (11) }\end{array}$} & Pillai's Trace & 1.388 & 1.276 & 80.000 & 192.000 & .090 & .347 & 102.082 & .999 \\
\hline & Wilks' Lambda & .172 & 1.265 & 80.000 & 179.941 & .101 & .356 & 99.500 & .998 \\
\hline & $\begin{array}{l}\text { Hotelling's } \\
\text { Trace }\end{array}$ & 2.297 & 1.249 & 80.000 & 174.000 & .115 & .365 & 99.925 & .998 \\
\hline & $\begin{array}{l}\text { Roy's Largest } \\
\text { Root }\end{array}$ & .913 & $2.192^{\mathrm{c}}$ & 20.000 & 48.000 & .013 & .477 & 43.842 & .964 \\
\hline \multirow{6}{*}{$\begin{array}{l}\text { Emphasizes the } \\
\text { corporate vision } \\
\text { (12) }\end{array}$} & Pillai's Trace & 1.318 & 1.180 & 80.000 & 192.000 & .181 & .330 & 94.381 & .997 \\
\hline & Wilks' Lambda & .185 & 1.203 & 80.000 & 179.941 & .158 & .345 & 94.584 & .997 \\
\hline & Hotelling's & 2.244 & 1.220 & 80.000 & 174.000 & .141 & .359 & 97.631 & .997 \\
\hline & Trace & & & & & & & & \\
\hline & Roy's Largest & 1.073 & $2.575^{\mathrm{c}}$ & 20.000 & 48.000 & .004 & .518 & 51.493 & .986 \\
\hline & Root & & & & & & & & \\
\hline
\end{tabular}




\begin{tabular}{|c|c|c|c|c|c|c|c|c|c|}
\hline Effect & & Value & $\mathrm{F}$ & $\begin{array}{l}\text { Hypothesis } \\
\text { df }\end{array}$ & Error df & Sig. & $\begin{array}{l}\text { Partial Eta } \\
\text { Squared }\end{array}$ & $\begin{array}{l}\text { Noncent. } \\
\text { Parameter }\end{array}$ & $\begin{array}{l}\text { Observed } \\
\text { Power }^{\mathrm{d}}\end{array}$ \\
\hline \multirow{4}{*}{$\begin{array}{l}\text { Delays } \\
\text { answering } \\
\text { urgent } \\
\text { questions } \\
\text { (13) }\end{array}$} & Pillai's Trace & 1.345 & 1.216 & 80.000 & 192.000 & .141 & .336 & 97.309 & .998 \\
\hline & Wilks' Lambda & .184 & 1.207 & 80.000 & 179.941 & .153 & .345 & 94.897 & .997 \\
\hline & Hotelling's Trace & 2.194 & 1.193 & 80.000 & 174.000 & .170 & .354 & 95.442 & .997 \\
\hline & Roy's Largest Root & .923 & $2.216^{\mathrm{c}}$ & 20.000 & 48.000 & .012 & .480 & 44.314 & .966 \\
\hline \multirow{3}{*}{$\begin{array}{l}\text { Produces } \\
\text { new projects } \\
\text { (14) }\end{array}$} & Wilks' Lambda & .187 & 1.193 & 80.000 & 179.941 & .168 & .343 & 93.823 & .996 \\
\hline & Hotelling's Trace & 2.191 & 1.191 & 80.000 & 174.000 & .172 & .354 & 95.293 & .997 \\
\hline & Roy's Largest Root & .934 & $2.242^{\mathrm{c}}$ & 20.000 & 48.000 & .011 & .483 & 44.846 & .968 \\
\hline
\end{tabular}

a. Design: Intercept $+10+11+12+13+14$

b. Exact statistic

c. The statistic is an upper bound on $\mathrm{F}$ that yields a lower bound on the significance level.

d. Computed using alpha $=.05$

An immediate attention-taking result is that none of the items within this leadership style is able to affect job satisfaction. In other words, managers' perceived productive leadership style does not affect workers' job satisfaction.

Third perceived leadership factor is laissez-faire style and Table 7 unearths its effects on workers' job satisfaction. 


\section{Macrothink}

Case Studies in Business and Management

ISSN 2333-3324

2018, Vol. 5, No. 1

Table 7. GLM results about perceived laissez-faire leadership style's effects on job satisfaction

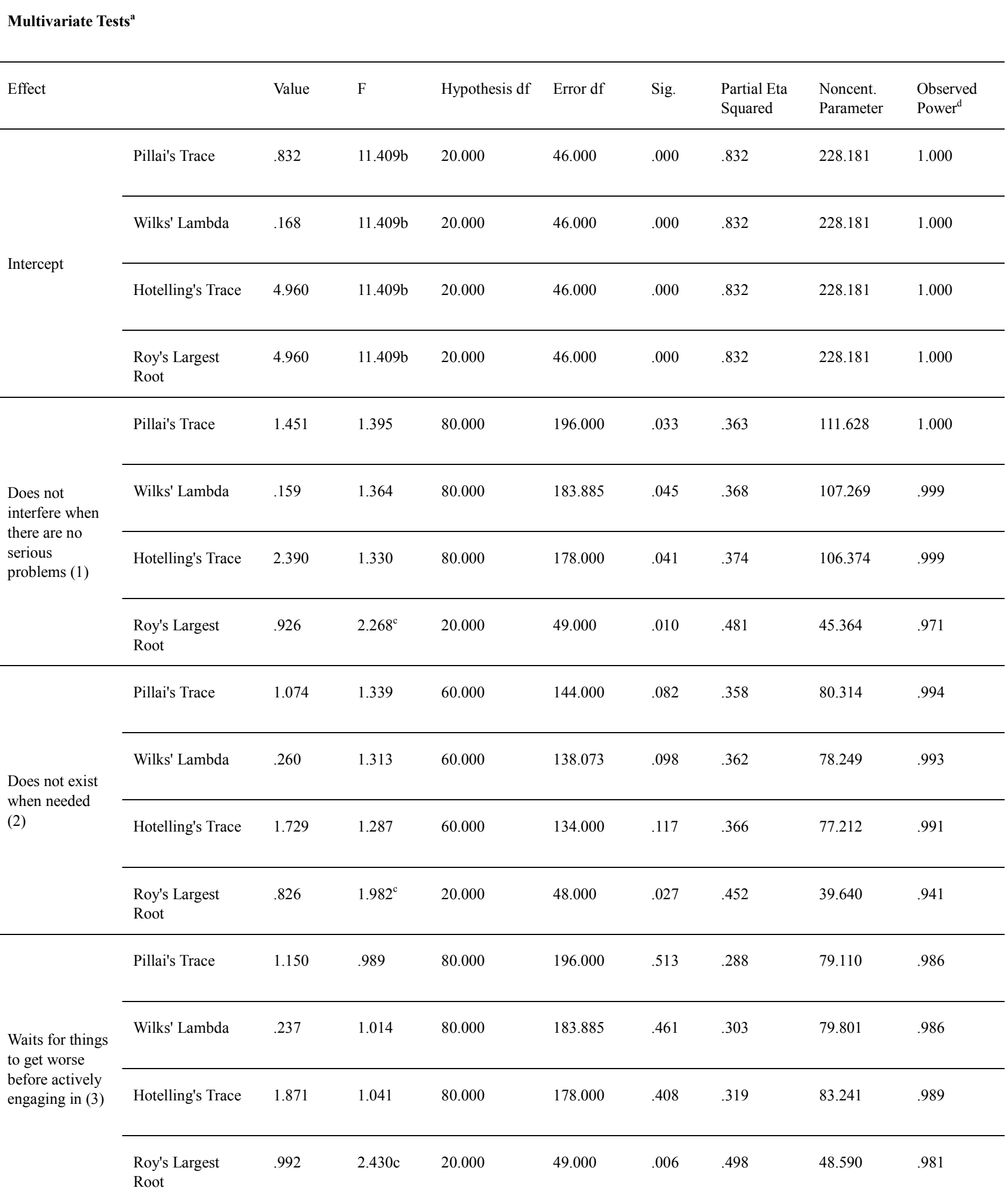




\begin{tabular}{|c|c|c|c|c|c|c|c|c|c|}
\hline Effect & & Value & $\mathrm{F}$ & $\begin{array}{l}\text { Hypothesis } \\
\text { df }\end{array}$ & Error df & Sig. & $\begin{array}{l}\text { Partial Eta } \\
\text { Squared }\end{array}$ & $\begin{array}{l}\text { Noncent. } \\
\text { Parameter }\end{array}$ & $\begin{array}{l}\text { Observed } \\
\text { Power }^{\mathrm{d}}\end{array}$ \\
\hline \multirow{4}{*}{$\begin{array}{l}\text { Does not clearly } \\
\text { manage us (4) }\end{array}$} & Pillai's Trace & 1.387 & 1.300 & 80.000 & 196.000 & .044 & .347 & 103.988 & .999 \\
\hline & Wilks' Lambda & .148 & 1.429 & 80.000 & 183.885 & .026 & .379 & 112.366 & 1.000 \\
\hline & Hotelling's Trace & 2.851 & 1.586 & 80.000 & 178.000 & .006 & .416 & 126.872 & 1.000 \\
\hline & $\begin{array}{l}\text { Roy's Largest } \\
\text { Root }\end{array}$ & 1.794 & $4.396 \mathrm{c}$ & 20.000 & 49.000 & .000 & .642 & 87.921 & 1.000 \\
\hline \multirow{3}{*}{$\begin{array}{l}\text { Provides } \\
\text { resources to } \\
\text { workers in order } \\
\text { to reach the } \\
\text { specified } \\
\text { objectives (5) }\end{array}$} & Wilks' Lambda & .134 & 1.529 & 80.000 & 183.885 & .010 & .395 & 120.148 & 1.000 \\
\hline & Hotelling's Trace & 2.759 & 1.535 & 80.000 & 178.000 & .010 & .408 & 122.797 & 1.000 \\
\hline & $\begin{array}{l}\text { Roy's Largest } \\
\text { Root }\end{array}$ & 1.251 & $3.064^{\mathrm{c}}$ & 20.000 & 49.000 & .001 & .556 & 61.275 & .997 \\
\hline
\end{tabular}

a. Design: Intercept $+1+2+3+4+5$

b. Exact statistic

c. The statistic is an upper bound on F that yields a lower bound on the significance level.

Similar to the case with the inspirational style, there is a partial effect of perceived laissez-faire leadership style on the job satisfaction. More precisely the items; "Does not interfere when there are no serious problems", "Does not clearly manage us", and "Provides resources to workers in order to reach the specified objectives" can affect workers' job satisfaction.

The last factor's (success orientation) effects on workers' job satisfaction are included in Table 8. 
Table 8. GLM results about perceived success orientation style's effects on job satisfaction

\section{Multivariate Tests ${ }^{\mathrm{a}}$}

\begin{tabular}{|c|c|c|c|c|c|c|c|c|c|}
\hline \multicolumn{2}{|l|}{ Effect } & Value & $\mathrm{F}$ & Hypothesis df & Error df & Sig. & $\begin{array}{l}\text { Partial Eta } \\
\text { Squared }\end{array}$ & $\begin{array}{l}\text { Noncent. } \\
\text { Parameter }\end{array}$ & $\begin{array}{l}\text { Observed } \\
\text { Power }^{\mathrm{d}}\end{array}$ \\
\hline \multirow{4}{*}{ Intercept } & Pillai's Trace & .936 & $39.000^{\mathrm{b}}$ & 20.000 & 53.000 & .000 & .936 & 780.004 & 1.000 \\
\hline & Wilks' Lambda & .064 & $39.000^{\mathrm{b}}$ & 20.000 & 53.000 & .000 & .936 & 780.004 & 1.000 \\
\hline & Hotelling's Trace & 14.717 & $39.000^{\mathrm{b}}$ & 20.000 & 53.000 & .000 & .936 & 780.004 & 1.000 \\
\hline & Roy's Largest Root & 14.717 & $39.000^{\mathrm{b}}$ & 20.000 & 53.000 & .000 & .936 & 780.004 & 1.000 \\
\hline \multirow{4}{*}{$\begin{array}{l}\text { Produces } \\
\text { appropriate and } \\
\text { constructive } \\
\text { solutions for } \\
\text { problems (7) }\end{array}$} & Pillai's Trace & 1.507 & 1.692 & 80.000 & 224.000 & .001 & .377 & 135.346 & 1.000 \\
\hline & Wilks' Lambda & .134 & 1.756 & 80.000 & 211.500 & .001 & .395 & 138.041 & 1.000 \\
\hline & Hotelling's Trace & 2.812 & 1.810 & 80.000 & 206.000 & .000 & .413 & 144.832 & 1.000 \\
\hline & Roy's Largest Root & 1.289 & $3.608^{\mathrm{c}}$ & 20.000 & 56.000 & .000 & .563 & 72.164 & 1.000 \\
\hline \multirow{4}{*}{$\begin{array}{l}\text { Makes } \\
\text { motivational } \\
\text { speeches to } \\
\text { achieve success } \\
\text { (8) }\end{array}$} & Pillai's Trace & .961 & .886 & 80.000 & 224.000 & .733 & .240 & 70.875 & .975 \\
\hline & Wilks' Lambda & .323 & .878 & 80.000 & 211.500 & .747 & .246 & 69.136 & .968 \\
\hline & Hotelling's Trace & 1.350 & .869 & 80.000 & 206.000 & .763 & .252 & 69.520 & .968 \\
\hline & Roy's Largest Root & .560 & $1.568 \mathrm{c}$ & 20.000 & 56.000 & .095 & .359 & 31.353 & .872 \\
\hline \multirow{4}{*}{$\begin{array}{l}\text { Emphasizes } \\
\text { mistakes. } \\
\text { complaints. and } \\
\text { deficiencies (9) }\end{array}$} & Pillai's Trace & 1.192 & 1.189 & 80.000 & 224.000 & .163 & .298 & 95.136 & .998 \\
\hline & Wilks' Lambda & .233 & 1.179 & 80.000 & 211.500 & .177 & .305 & 92.806 & .997 \\
\hline & Hotelling's Trace & 1.810 & 1.165 & 80.000 & 206.000 & .196 & .312 & 93.220 & .997 \\
\hline & Roy's Largest Root & .651 & $1.822 \mathrm{c}$ & 20.000 & 56.000 & .041 & .394 & 36.450 & .927 \\
\hline
\end{tabular}

a. Design: Intercept $+7+8+9$

b. Exact statistic

c. The statistic is an upper bound on $\mathrm{F}$ that yields a lower bound on the significance level.

d. Computed using alpha $=.05$ 


\section{Mll Macrothink}

Case Studies in Business and Management

ISSN 2333-3324

2018, Vol. 5, No. 1

There is again a partial effect observed in Table 8 - immediate managers' perceived success orientation leadership style can solely affect workers' job satisfaction partially. Only the item "Produces appropriate and constructive solutions for problems" is able to affect the job satisfaction.

When all achieved GLM results are considered together, the main hypothesis is rejected (Table 9).

Table 9. Overall results and hypothesis testing result

\begin{tabular}{ll}
\hline Perceived Leadership Factor & Is It Effective on Workers' Job Satisfaction? \\
\hline Inspirational Leadership Style & Yes, partially. \\
Productive Leadership Style & No. \\
Laissez-faire Style & Yes, partially. \\
Success Orientation & Yes, partially. \\
\hline
\end{tabular}

The Research Hypothesis

Ho: Workers' perceptions about their immediate managers' leadership affect their own job satisfaction.

IS REJECTED.

\section{Conclusion}

This study scrutinizes relationships between two very popular subjects - job satisfaction and leadership - in a context, which has not been much considered before. This particularity is also present in terms of the main result: workers' perceived leadership of their immediate managers fails to affect their own job satisfaction completely, thus there are solely partial effects. While a comparison with the literature reveals that this result is not in full conformity with the consensus that leadership affects job satisfaction, partial effects obtained still imply coherence.

A detailed look on these partial affects necessitates the factors of perceived leadership and job satisfaction. Workers' job satisfaction is found out to depend on four main factors. Although three of these; namely task, and social, and managerial aspects are very common in the literature; the fourth one (institutional aspect) is relatively rare. In other words, workers not only consider how they perform their tasks, interact with their peers and managers, feel appreciated, and professionalism of their immediate managers; but also take their businesses' professionalism into consideration if the question is their job satisfaction.

Workers, moreover, perceive that their immediate managers could bear leader characteristics and these depend on four leadership styles. Accordingly, immediate managers are considered to inspire the workers, focus on working and producing, emphasize an interest towards 
success, and set workers free and unattended.

As already mentioned, workers' perceptions about their immediate managers' leadership cannot fully affect these workers' job satisfaction, albeit there are some connections among the factors of perceived leadership and job satisfaction. For instance, some items of perceived inspirational leadership are found out to affect workers' job satisfaction. An aggregation of these items reveals that they are about perceived leader's altruism, unity, and optimism. In other words, workers believe that their immediate managers have inspirational leadership style and only altruism, unity, and optimism aspects of this style are effective on their job satisfaction. The situation is similar when perceived laissez-faire leadership style is considered-immediate managers exert this leadership style, and its items regarding setting workers free and providing resources can affect workers' job satisfaction. When success orientation feature of leadership is under the spotlights, only one item affects workers' job satisfaction and it is about perceived leader's constructive problem solving skills. Despite these partial effects, the fourth leadership factor - productive leadership style - is unable to affect workers' job satisfaction.

As a last point, some suggestions for the future could be made. Future studies may check leadership and job satisfaction connections in various other settings. They may also focus on specific aspects of leadership such as leadership types and compare these types according to their effects on job satisfaction. Similarly, job satisfaction may be taken into account via some of its aspects. There may also be additions of some other subjects into the leadership-job satisfaction relationship and these additions could be related to personal features, organizational characteristics, or organizational subjects. Other than these scientific suggestions, a clear suggestion for the business context is that leadership practices should be evaluated and exerted appropriately in order to foster job satisfaction of workers.

\section{References}

Ali, N., Jan, S., Ali, A., \& Tariq, M. (2014). Transformational and transactional leadership as predictors of job satisfaction, commitment, perceived performance and turnover intention (Empirical evidence from Malakand division, Pakistan). Life Science Journal, 11(5), 48-53.

Arvey, R. D., Carter, G. W., \& Buerkley, D. K. (1991). Job satisfaction: Dispositional and situational influences. International Review of Industrial and Organizational Psychology, 6, 359-383.

Ayranci, E., \& Semercioz, F. (2011). The relationship between spiritual leadership and issues of spirituality and religiosity: A study of top Turkish managers. International Journal of Business and Management, 6(4), 136-149. https://doi.org/10.5539/ijbm.v6n4p136

Bellows, R. (1959). Creative leadership. Oxford, England: Prentice-Hall.

Berry, J. W. (1997). Immigration, acculturation and adaptation. Applied Psychology, 46, 5-68. https://doi.org/10.1111/j.1464-0597.1997.tb01087.x

Blackburn, R. T., \& Lawrence, J. H. (1995). Faculty at work: Motivation, expectation, satisfaction. Johns Hopkins University Press. 


\section{Macrothink}

Case Studies in Business and Management ISSN 2333-3324 2018, Vol. 5, No. 1

Bogardus, E. S. (1929). American attitudes towards the Filipinos. Sociology \& Social Research, 14, 59-69.

Bono, J. E., \& Judge, T. A. (2003). Self-concordance at work: Toward understanding the motivational effects of transformational leaders. Academy of Management Journal, 46(5), 554-571.

Braun, S., Peus, C., Weisweiler, S., \& Frey, D. (2013). Transformational leadership, job satisfaction, and team performance: A multilevel mediation model of trust. The Leadership Quarterly, 24(1), 270-283. https://doi.org/10.1016/j.leaqua.2012.11.006

Bryant, S. E. (2003). The role of transformational and transactional leadership in creating, sharing and exploiting organizational knowledge. Journal of Leadership \& Organizational Studies, 9(4), 32-44. https://doi.org/10.1177/107179190300900403

Butler, D. (1993). Business studies. Great Britain: Oxford University Press.

Calder, B. J. (1977). An attribution theory of leadership. USA: St. Clair Press.

Caliskan, Z. (2005). Job satisfaction: An application on health institutions in Eastern Anatolian Region (In Turkish). Master's thesis, İnönü University, Turkey.

Cater, J. J. (2006). Stepping out of the shadow: The leadership qualities of successors in family business. Doctoral dissertation, Louisiana State University, USA.

Chung-Wen, Y. (2008). The relationships among leadership styles, entrepreneurial orientation, and business performance. Managing Global Transitions, 6(3), 257-275.

Chusmir, L. H., \& Parker, B. (2001). Success strivings and their relationship to affective work behaviors: Gender differences. The Journal of Social Psychology, 132, 87-99. https://doi.org/10.1080/00224545.1992.9924691

Cohen, M. (1972). The stimulation of men in business, principles and techniques. Paris: Organizational Publishing.

Colbert, F. (2003). Entrepreneurship and leadership in marketing the arts. International Journal of Arts Management, 6(1), 30-39.

Cowley, W. H. (1928). Three distinctions in the study of leaders. Journal of Abnormal and Social Psychology, 23, 144-157. https://doi.org/10.1037/h0073661

Dansereau, F., Graen, G., \& Haga, W. J. (1975). A vertical dyad linkage approach to leadership within formal organizations: A longitudinal investigation of the role making process. Organizational behavior and human performance, 13(1), 46-78. https://doi.org/10.1016/0030-5073(75)90005-7

Davis, K., \& Newstrom, C. W. (1985). Human behaviour at work (Management). New York: McGraw Hill Higher Education. 


\section{Al Macrothink}

Case Studies in Business and Management ISSN 2333-3324 2018, Vol. 5, No. 1

Dede, N. P., \& Ayranci, E. (2014). Exploring the connections among spiritual leadership, altruism, and trust in family businesses. Quality \& Quantity, 48(6), 3373-3400. https://doi.org/10.1007/s11135-013-9962-x

DeGroot, T., Kiker, D. S., \& Cross, T. C. (2000). A meta-analysis to review organizational outcomes related to charismatic leadership. Canadian Journal of Administrative Sciences, 17, 356-371. https://doi.org/10.1111/j.1936-4490.2000.tb00234.x

Denes, C. A. (2003). Bolsaescola: Redefining poverty and development in Brazil. International Education Journal, 4, 137-147.

Eagly, A. H., \& Carli, L. L. (2007). Women and the labyrinth of leadership. Harvard Business Review, 85(9), 62-79.

Epitropaki, O., \& Martin, R. (2013). Transformational-transactional leadership and upward influence: The role of relative leader-member exchanges (RLMX) and perceived organizational support (POS). Leadership Quarterly, 24, 299-315. https://doi.org/10.1016/j.leaqua.2012.11.007

Erdil, O., Keskin, H., İmamoğlu, S. Z., \& Erat, S. (2004). Relationships between management style, working conditions, friendship context, and the feeling of appreciation and job satisfaction (In Turkish). Doğuş University Journal, 5(1), 17-26.

Eren, E. (2000). Organizational behaviour and management psychology (In Turkish). İstanbul: Beta Publications.

Fairbrother, K., \& Warn, J. (2003). Workplace dimensions, stress and job satisfaction. Journal of Managerial Psychology, 18(1), 8-21. https://doi.org/10.1108/02683940310459565

Faragher, E. B., Cass, M., \& Cooper, C. L. (2005). The relationship between job satisfaction and health: A meta-analysis. Occupational and Environmental Medicine, 62(2), 105-112. https://doi.org/10.1136/oem.2002.006734

Fiedler, F. (1967). A theory of leadership effectiveness. New York: McGraw-Hill.

Frooman, J., Mendelson, M. B., \& Kevin Murphy, J. (2012). Transformational and passive avoidant leadership as determinants of absenteeism. Leadership \& Organization Development Journal, 33(5), 447-463. https://doi.org/10.1108/01437731211241247

Fu, W., Deshpande, S. P., \& Zhao, X. (2011). The impact of ethical behavior and facets of job satisfaction on organizational commitment of Chinese employees. Journal of Business Ethics, 104(4), 537-543. https://doi.org/10.1007/s10551-011-0928-4

Galbreath, J., \& Rogers, T. (1999). Customer relationship leadership: A leadership and motivation model for the twenty-first century business. The TQM Magazine, 11(3), 161-171. https://doi.org/10.1108/09544789910262734 


\section{Macrothink}

Case Studies in Business and Management

ISSN 2333-3324

2018, Vol. 5, No. 1

Gardner, J., \& Oswald, A. (2002). How does education affect mental well-being and job satisfaction? Retrieved from https:/warwick.ac.uk/fac/soc/economics/staff/ajoswald/ reveducationgardneroswaldjune2002.pdf

Gehring, D. R. (2007). Applying traits theory of leadership to project management. Project Management Quarterly, 38(1), 44-54. https://doi.org/10.1109/EMR.2007.4296434

Gibb, C. A. (1954). Leadership. In G. Lindzey (Ed.), Handbook of Social Psychology (Vol. 2, pp. 877-917). Reading, MA: Addison-Wesley.

Guney, S., \& Arikan, S. (1994). Change leadership (In Turkish). Verimlilik Journal, 2, 139-148.

Harter, J. K., Schmidt, F. L., \& Keyes, C. L. (2003). Well-being in the workplace and its relationship to business outcomes: A review of the Gallup studies. Flourishing Positive Psychology and the Life Well-lived, 2, 205-224. https://doi.org/10.1037/10594-009

Hemphill, J. K., \& Coons, A. E. (1950). Leader behavior description. Columbus: Ohio State University, Personnel Research Board.

Heponiemi, T., Kouvonen, A., Virtanen, M., Vanska, J., \& Elovainio, M. (2014). The prospective effects of workplace violence on physicians' job satisfaction and turnover intentions: the buffering effect of job control. BMC Health Services Research, 14(1), 19-27. https://doi.org/10.1186/1472-6963-14-19

House, R. J., Hanges, P. J., Javidan, M., Dorfman, P. W., \& Gupta, V. (2004). Culture, leadership, and organizations: The GLOBE study of 62 societies. USA: Sage publications.

Howell, J. M., \& Avolio, B. J. (1993). Transformational leadership, transactional leadership, locus of control, and support for innovation: Key predictors of consolidated-business-unit performance. Journal of Applied Psychology, 78(6), 891-902. https://doi.org/10.1037/ 0021-9010.78.6.891

Howell, J. M., \& Shamir, B. (2005). The role of followers in the charismatic leadership process: Relationships and their consequences. Academy of Management Review, 30(1), 96-112. https://doi.org/10.5465/amr.2005.15281435

Ireland, R. D., \& Hitt, M. A. (1999). Achieving and maintaining strategic competitiveness in the 21st century: The role of strategic leadership. The Academy of Management Executive, 13(1), 43-57. https://doi.org/10.5465/ame.1999.1567311

Iscan, O. F., \& Timuroglu, M. K. (2007). Effect of organizational culture on job satisfaction and an application. Atatürk University Journal of Economics and Administrative Sciences, 21(1), 119-136.

James, W. (1880). Great men, great thoughts and their environment. Atlantic Monthly, 46, 441-459. 
Janda, K. F. (1960). Towards the explication of the concept of leadership in terms of the concept of power. Human Relations, 13(4), 345-363. https://doi.org/10.1177/ 001872676001300404

Jennings, H. H. (1944). Leadership-A dynamic redefinition. The Journal of Educational Sociology, 17(7), 431-433. https://doi.org/10.2307/2262553

Judge, T. A. (2000). Promote job satisfaction through mental challenge. In E. A. Locke (Ed.), Handbook of Principles of Organizational Behavior (pp. 75-89). Oxford, UK: Blackwell Publishing Ltd.

Judge, T. A., \& Piccolo, R. F. (2004). Transformational and transactional leadership: A meta-analytic test of their relative validity. Journal of Applied Psychology, 89, 755-768. https://doi.org/10.1037/0021-9010.89.5.755

Judge, T. A., \& Watanabe, S. (1993). Another look at the job satisfaction-life satisfaction relationship. Journal of Applied Psychology, 78(6), 939-948. https://doi.org/10.1037/ 0021-9010.78.6.939

Kallampally, G. A., Oakes, K. E., Lyons, H. Z., Greer, J. M., \& Gillespie, C. K. (2008). Gender, psychological resilience, acculturation and spirituality as predictors of Asian Indian American marital satisfaction. Journal of Spirituality in Mental Health, 10(1), 35-52. https://doi.org/10.1300/J515v10n01_04

Kalliath, T., \& Morris, R. (2002). Job satisfaction among nurses: A predictor of burnout levels. Journal of Nursing Administration, 32, 648-651. https://doi.org/10.1097/00005110200212000-00010

Kanste, O., Kyngas, H., \& Nikkila, J. (2007). The relationship between multidimensional leadership and burnout among nursing staff. Journal of Nursing Management, 15(7), 731-739. https://doi.org/10.1111/j.1365-2934.2006.00741.x

Kellett, J. B., Humphrey, R. H., \& Sleeth, R. G. (2002). Empathy and complex task performance: Two routes to leadership. The Leadership Quarterly, 13(5), 523-544. https://doi.org/10.1016/S1048-9843(02)00142-X

Keskin, H., Imamoglu, S. Z., \& Erat, S. (2004). Relationships among pay, career and creativity: An application in textile sector. Celal Bayar University Journal of Management and Organization, 11(1), 167-176.

Korman, A. X. (1966). Consideration, initiating structure, and organizational criteria - A review. Personnel. Psychology, 19, 349-361. https://doi.org/10.1111/j.1744-6570.1966. tb00310.x

Kovner, C., Brewer, C., Wu, Y. W., Cheng, Y., \& Suzuki, M. (2006). Factors associated with work satisfaction of registered nurses. Journal of Nursing Scholarship, 38(1), 71-79. https://doi.org/10.1111/j.1547-5069.2006.00080.x 
Kutlay, M. (2011). Effects of workers'personal features on their job satisfaction and burnout: A research in banking sector (In Turkish). Master's thesis, Nigde University, Turkey.

Kyriacou, C. (2001). Teacher stress: Directions for future research. Educational Review, 53, 27-35. https://doi.org/10.1080/00131910120033628

Lavy, S., \& Littman-Ovadia, H. (2017). My better self: Using strengths at work and work productivity, organizational citizenship behavior, and satisfaction. Journal of Career Development, 44(2), 95-109. https://doi.org/10.1177/0894845316634056

Leung, D. Y. P., \& Lee, W. W. S. (2006). Predicting intention to quit among Chinese teachers: Differential predictability of the component of burnout. Anxiety, Stress, \& Coping, 19, 129-141. https://doi.org/10.1080/10615800600565476

Liden, R. C., Wayne, S. J., Zhao, H., \& Henderson, D. (2008). Servant leadership: Development of a multidimensional measure and multi-level assessment. The Leadership Quarterly, 19(2), 161-177. https://doi.org/10.1016/j.leaqua.2008.01.006

Lindgren, P. (2012). Business model innovation leadership: How do SME's strategically lead business model innovation? International Journal of Business and Management, 7(14), 53-66. https://doi.org/10.5539/ijbm.v7n14p53

Mason, E. S. (1994). Gender differences in job satisfaction. The Journal of Social Psychology, 135, 143-151. https://doi.org/10.1080/00224545.1995.9711417

McDonald, D. J., \& Makin, P. J. (2000). The psychological contract, organizational commitment and job satisfaction of temporary staff. Leadership \& Organization Development Journal, 21(2), 84-91. https://doi.org/10.1108/01437730010318174

Meyer, J. P., Paunonen, S. V., Gellatly, I. R., Coffin, R. D., \& Jackson, D. N. (1989). Organizational commitment and job performance: It's the nature of the commitment that counts. Journal of Applied Psychology, 74, 152-156. https://doi.org/10.1037/00219010.74.1.152

Minkes, A. L., Small, M. W., \& Chatterjee, S. R. (1999). Leadership and business ethics: Does it matter? Implications for management. Journal of Business Ethics, 20(4), 327-335. https://doi.org/10.1023/A:1005741524800

Mouton, J. S., \& Blake, R. B. (1984). Synergy: A new strategy for education, training, and development. San Francisco: Jossey-Bass.

Mumford, T. V., Campion, M. A., \& Morgeson, F. P. (2007). The leadership skills strataplex: Leadership skill requirements across organizational levels. The Leadership Quarterly, 18(2), 154-166. https://doi.org/10.1016/j.leaqua.2007.01.005

Nadinloyi, K. B., Sadeghi, H., \& Hajloo, N. (2013). Relationship between job satisfaction and employees' mental health. Procedia - Social and Behavioral Sciences, 84, 293-297. https://doi.org/10.1016/j.sbspro.2013.06.554 
Nielsen, K., \& Daniels, K. (2016). The relationship between transformational leadership and follower sickness absence: The role of presenteeism. Work \& Stress, 30(2), 193-208. https://doi.org/10.1080/02678373.2016.1170736

Northouse, P. G. (2001). Leadership theory and practice (2nd ed.). London: Sage Publications.

Organ, D. W. (1988). A restatement of the satisfaction-performance hypothesis. Journal of Management, 14(4), 547-557. https://doi.org/10.1177/014920638801400405

Pelfrene, E., Vlerick, P., \& Moreau, M. (2003). Perceptions of job insecurity and the impact of world market competition as health risks: Results from Belstress. Journal of Occupational and Organizational Psychology, 76, 411-425. https://doi.org/10.1348/096317903322591569

Piko, B. F. (2006). Burnout, role conflict, job satisfaction and psychosocial health among Hungarian health care staff: A questionnaire survey. International Journal of Nursing Studies, 43(3), 311-318. https://doi.org/10.1016/j.ijnurstu.2005.05.003

Pillai, R., Schriesheim, C. A., \& Williams, E. S. (1999). Fairness perceptions and trust as mediators for transformational and transactional leadership: A two-sample study. Journal of Management, 25(6), 897-933. https://doi.org/10.1177/014920639902500606

Poghosyan, L., Liu, J., Shang, J., \& D’Aunno, T. (2017). Practice environments and job satisfaction and turnover intentions of nurse practitioners: Implications for primary care workforce capacity. Health Care Management Review, 42(2), 162-171. https://doi.org/10.1097/HMR.0000000000000094

Portugal, E., \& Yukl, G. (1994). Perspectives on environmental leadership. The Leadership Quarterly, 5(3-4), 271-276. https://doi.org/10.1016/1048-9843(94)90017-5

Redl, F. (1942). Group emotion and leadership. Psychiatry, 5(4), 573-596. https://doi.org/10.1080/00332747.1942.11022422

Sanli, S. (2006). An evaluation of job satisfaction and burnout levels of the police working in the city of Adana (In Turkish). Master's thesis, Çukurova University, Turkey.

Sarros, J. C., Cooper, B. K., \& Santora, J. C. (2008). Building a climate for innovation through transformational leadership and organizational culture. Journal of Leadership \& Organizational Studies, 15(2), 145-158. https://doi.org/10.1177/1548051808324100

Sarros, J. C., Tanewski, G. A., Winter, R. P., Santora, J. C., \& Densten, I. L. (2002). Work alienation and organizational leadership. British Journal of Management, 13(4), 285-304. https://doi.org/10.1111/1467-8551.00247

Schaumberg, R. L., \& Flynn, F. J. (2017). Clarifying the link between job satisfaction and absenteeism: The role of guilt proneness. Journal of Applied Psychology, 102(6), 982-992. https://doi.org/10.1037/ap10000208 
Seo, Y., Ko, J, \& Price, J. L. (2004). The determinants of job satisfaction among hospital nurses: A model estimation in Korea. International Journal of Nursing Studies, 41, 437-446. https://doi.org/10.1016/j.ijnurstu.2003.11.003

Shamir, B. (1991). Meaning, self and motivation in organizations. Organization Studies, 12(3), 405-424. https://doi.org/10.1177/017084069101200304

Simons, T. L. (1999). Behavioral integrity as a critical ingredient for transformational leadership. Journal of Organizational Change Management, 12(2), 89-104. https://doi.org/10.1108/09534819910263640

Simpson, M. R. (2009). Engagement at Work: A Review of the Literature. International Journal of Nursing Studies, 46(7), 1012-1024. https://doi.org/10.1016/j.ijnurstu.2008.05.003

Sin, L. Y., Tse, A. C., Yau, O. H., Lee, J. S., \& Chow, R. (2002). The effect of relationship marketing orientation on business performance in a service-oriented economy. Journal of Services Marketing, 16(7), 656-676. https://doi.org/10.1108/08876040210447360

Singh, P., Finn, D., \& Goulet, L. (2004). Gender and job attitudes: A re-examination and extension. Women in Management Review, 19, 345-355. https://doi.org/10.1108/ 09649420410563403

Spector, P. E. (1997). Job satisfaction: Application, assessment, causes, and consequences. Thousand Oaks, CA: Sage.

Staw, B. M., Bell, N. E., \& Clausen, J. A. (1986). The dispositional approach to job attitudes: A lifetime longitudinal test. American Science Quarterly, 31, 56-77. https://doi.org/10.2307/2392766

Stogdill, R. M. (1948). Personal factors associated with leadership: A survey of the literature. The Journal of Psychology, 25, 35-71. https://doi.org/10.1080/00223980.1948.9917362

Tetik, S., Ucar, G., \& Yalcin, B. (2008). Factors affecting job satisfaction in organizations and a field research about police officers (In Turkish). Verimlilik Journal, 1, 79-105.

Tichy, N. M., \& Devanna, M. A. (1986). The transformational leader. Training \& Development Journal, 40(7), 27-32.

Van Dierendonck, D. (2011). Servant leadership: A review and synthesis. Journal of Management, 37(4), 1228-1261. https://doi.org/10.1177/0149206310380462

Voegtlin, C., Patzer, M., \& Scherer, A. G. (2012). Responsible leadership in global business: A new approach to leadership and its multi-level outcomes. Journal of Business Ethics, 105(1), 1-16. https://doi.org/10.1007/s10551-011-0952-4

Vroom, V. H. (1964). The determination of job satisfaction at work and motivation. New York: John Wiley \& Sons, Inc.

Vroom, V. H., \& Yetton, P. W. (1973). Leadership and decision-making. Pittsburgh: University of Pittsburgh Press. https://doi.org/10.2307/j.ctt6wrc8r 


\section{Macrothink}

Waddimba, A. C., Beckman, H. B., Mahoney, T. L., \& Burgess Jr, J. F. (2017). The Moderating Effect of Job Satisfaction on Physicians' Motivation to Adhere to Financially Incentivized Clinical Practice Guidelines. Medical Care Research and Review, 74(2), 148-177. https://doi.org/10.1177/1077558716628354

Walumbwa, F. O., Avolio, B. J., Gardner, W. L., Wernsing, T. S., \& Peterson, S. J. (2008). Authentic leadership: Development and validation of a theory-based measure. Journal of Management, 34(1), 89-126. https://doi.org/10.1177/0149206307308913

Ward, J. (2011). Keeping the family business healthy: How to plan for continuing growth, profitability, and family leadership. New York: Palgrave Macmillan. https://doi.org/10.1057/ 9780230116122

Weiss, H. M. (2002). Deconstructing job satisfaction: Separating evaluations, beliefs and affective experiences. Human Resource Management Review, 12(2), 173-194. https://doi.org/10.1016/S1053-4822(02)00045-1

Wong, C. A., \& Cummings, G. G. (2007). The relationship between nursing leadership and patient outcomes: A systematic review. Journal of Nursing Management, 15(5), 508-521. https://doi.org/10.1111/j.1365-2834.2007.00723.x

Wright, B. E., \& Davis, B. S. (2003). Job satisfaction in the public sector: The role of the work environment. American Review of Public Administration, 33, 70-90. https://doi.org/10.1177/0275074002250254

Xenikou, A., \& Simosi, M. (2006). Organizational culture and transformational leadership as predictors of business unit performance. Journal of Managerial Psychology, 21(6), 566-579. https://doi.org/10.1108/02683940610684409

Zhao, H., Wayne, S. J., Glibkowski, B. C., \& Bravo, J. (2007). The impact of psychological contract breach on work-related outcomes: A meta-analysis. Personnel Psychology, 60, 647-680. https://doi.org/10.1111/j.1744-6570.2007.00087.x

\section{Copyrights}

Copyright for this article is retained by the author(s), with first publication rights granted to the journal.

This is an open-access article distributed under the terms and conditions of the Creative Commons Attribution license (http://creativecommons.org/licenses/by/4.0/). 